\title{
Australian Journal of Crop Science \\ Biofertilizer increases the production and yield of sunflower (Helianthus annuus L.) oil in soils with adequate water availability
}

\section{Marcelo de Andrade Barbosa ${ }^{1}$, Geffson de Figueredo Dantas ${ }^{2}$, Rener Luciano de Souza Ferraz ${ }^{3}$, Evandro Franklin de Mesquita ${ }^{4}$, Francisco Vanies da Silva Sá ${ }^{3 *}$, Alberto Soares de Melo ${ }^{5}$}

${ }^{1}$ Department of Soils and Fertilizers, São Paulo State University (FCAV/UNESP), Jaboticabal, SP, Brazil

${ }^{2}$ Department of Agricultural Engineering, São Paulo State University (FCAV/UNESP), Jaboticabal, SP, Brazil

${ }^{3}$ Department of Agricultural Engineering, Federal University of Campina Grande, Campina Grande, PB, Brazil

${ }^{4}$ Department of Agricultural and Exact Sciences, Paraíba State University (UEPB), Catolé do Rocha, PB, Brazil

${ }^{5}$ Department of Agricultural Sciences, Paraíba State University/Embrapa Cotton, Campina Grande, PB, Brazil

\section{*Corresponding author: vanies_agronomia@hotmail.com}

\begin{abstract}
The experiment was carried out with the goal of evaluating the productive aspects of sunflower cultivar Helium 253, in respon se to the application of cattle biofertilizer and levels of water availability in two types of soils. A completely randomized experimental design was adopted using the factorial $2 \times 2 \times 5$ for the 2 types of soils: Entisol and Alfisol, two levels of water availability in the soil ( 100 and $50 \%$ of moisture retention capacity, and five rates of liquid cattle biofertilizer corresponding to $0 ; 0.75 ; 1.5 ; 2.25$ and $3 \mathrm{~L}$ plant $^{-1}$, prepared in the proportion of water 1:3. Sunflower plants were cultivated in pots with $30 \mathrm{~L}$ volume, individually filled with each type of soil, with daily water supply made based on humidity readings determined in the pots, using a capacitance multisensor probe type PR2/6 (Time Domain Reflectometry - TDR). To evaluate the sunflower production, the following variables were measured: internal diameter (IDH) and outer diameter of the head (ODH), number of seeds per plant (NSP), weight of 100 seeds (W100S) and oil content in seeds (OCS) and water consumption per plant (WCP). Among the studied soils, Entisol is the one that presents the best conditions for the production of the sunflower cv. Helium 253, being also the soil where the highest water consumption by plant occurs. For Entisol, it is recommended the rate of cattle biofertilizer estimated in $1.05 \mathrm{~L} \mathrm{plant}^{-1}$, and for Alfisol the rate of $3 \mathrm{~L} \mathrm{plant}^{-1}$. Regardless of the soil used, the highest production values are obtained when the soil was maintained with $100 \%$ of moisture retention capacity.
\end{abstract}

Keywords: fertilization, irrigation, productivity.

Introduction

Sunflower (Helianthus annuus L.) is one of the four largest oilseed crops producing edible vegetable oil in use worldwide. It is successfully cultivated on five continents, in more than 25 million hectares (Oliveira, 2015). However, the increase in production area in recent years is mainly due to the importance of sunflower as a source of raw material for the production of renewable energy (Gatto et al., 2015). One of the most important constraints for plant development in semiarid regions is the water deficit (González et al., 2015). Irrigation is a technique that can overcome the water deficiency of plants and increase productivity, providing better quality products with a good price perspective in the market (Silva et al., 2007). In many areas of agricultural production around the world, inadequate irrigation and mineral fertilizer management are the major causes of soil degradation problems and low agricultural production.

The physical characteristics of the soil, such as aggregation, macro and micro porosity, water retention capacity, content of organic matter, sand, silt and clay influence the volume of water to be applied, even in similar climatic conditions, and may vary in function of the soil type (Maia Filho et al., 2013). The Neossolos (Entisols) and
Luvissolos (Alfisols) are the two types of soil that have the greatest predominance in the semiarid region of the state of Paraíba, Brazil, existing the need to carry out studies that can characterize the productive behavior of sunflower under these conditions, so that management strategies can be elaborated in order to obtain high productivity. Associated with irrigation management, organic fertilization is another important factor for cultivation. For example, cattle biofertilizers can provide improvements in the chemical, physical and biological characteristics of the soil (Rivera-Cruz et al., 2008), which can act as an alternative to minimize expenses with synthetic fertilizers, and add greater value to the final product, mainly for small family farmers. There are scarce studies aimed at the use of cattle biofertilizer associated with water supply in the soil as an agricultural alternative for semiarid regions. Thus, this experiment was performed with the objective of evaluating the production of sunflower hybrid Helium 253, in two soil types under different water availability levels and cattle biofertilizer rates. 
Table 1. Values of $\mathrm{pH}$, electrical conductivity and cattle biofertilizer composition 45 days after the start of anaerobic fermentation.

\begin{tabular}{|c|c|c|c|c|c|c|c|c|c|}
\hline $\mathrm{pH}$ & $\mathrm{EC}$ & $\mathrm{Ca}^{+2}$ & $\mathrm{Mg}^{+2}$ & $\mathrm{Na}^{+}$ & $\mathrm{K}^{+}$ & $\mathrm{Cl}^{-}$ & $\mathrm{CO}_{3}{ }^{2-}$ & $\mathrm{HCO}_{3}{ }^{-}$ & $\mathrm{SO}_{4}{ }^{2-}$ \\
\hline & $\mathrm{dS} \mathrm{m}^{-1}$ & $\ldots \ldots .$. & ........ & ........... & & ...... & 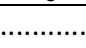 & & \\
\hline 6.34 & 1.08 & 3.71 & 2.40 & 3.27 & 1.69 & 5.59 & 0.43 & 2.03 & 3.02 \\
\hline
\end{tabular}

EC $=$ electrical conductivity of the biofertilizer.

Table 2. Summary of the variance analysis for the variables internal diameter of the head (IDH), outer diameter of the head (ODH), number of seeds per plant (NSP), weight of 100 seeds (W100S), oil content in the seeds (OCS) and water consumption per plant (WCP) of the sunflower hybrid Helium 253, Catolé do Rocha municipality - Paraíba.

\begin{tabular}{|c|c|c|c|c|c|c|c|}
\hline \multicolumn{8}{|l|}{ Average Square } \\
\hline SV & DF & IDH & $\mathrm{ODH}$ & NSP & W100S & OCS & WCP \\
\hline Biofertilizer (B) & 4 & $1269^{* *}$ & $2182^{* *}$ & $19511^{\text {ns }}$ & $3.58^{*}$ & $56.22^{* *}$ & $173^{* *}$ \\
\hline Soils (S) & 1 & $15152^{* *}$ & $23253^{* *}$ & $801108^{* *}$ & $34.65^{* *}$ & $219.88^{* *}$ & $25741^{* *}$ \\
\hline Levels (L) & 1 & $78214^{* *}$ & $96032^{* *}$ & $124479^{* *}$ & $2.16^{\mathrm{ns}}$ & $0.53^{\mathrm{ns}}$ & $25357^{* *}$ \\
\hline Int. B x S & 4 & $881^{* *}$ & $1565^{\mathrm{ns}}$ & $188532^{* *}$ & $1.81^{\mathrm{ns}}$ & $183.14^{* *}$ & $1047^{* *}$ \\
\hline Int. $B \times L$ & 4 & $3579^{* *}$ & $4473^{* *}$ & $441378^{* *}$ & $1.76^{\mathrm{ns}}$ & $106.20^{* *}$ & $498^{* *}$ \\
\hline Int. S x L & 1 & $550^{\mathrm{ns}}$ & $121^{\mathrm{ns}}$ & $1782^{\mathrm{ns}}$ & $11.44^{* *}$ & $3.10^{\mathrm{ns}}$ & $876^{* *}$ \\
\hline Int. $B \times S \times L$ & 4 & $749^{* *}$ & $1336^{\mathrm{ns}}$ & $368169^{* *}$ & $1.99^{\mathrm{ns}}$ & $133.51^{* *}$ & $972^{* *}$ \\
\hline Residue & 152 & 47.18 & 175.18 & 10653 & 0.35 & 0.70 & 0.23 \\
\hline CV (\%) & & 6.79 & 11.98 & 13.48 & 10.18 & 2.08 & 0.69 \\
\hline
\end{tabular}

SV, sources of variation; Int., Interaction; DF, degree of freedom; ${ }^{*},{ }^{* *}$ and ${ }^{\text {ns }}$ significant at $5 \%$. and at $1 \%$ probability and not significant by the $\mathrm{F}$ test; CV, coefficient of variation
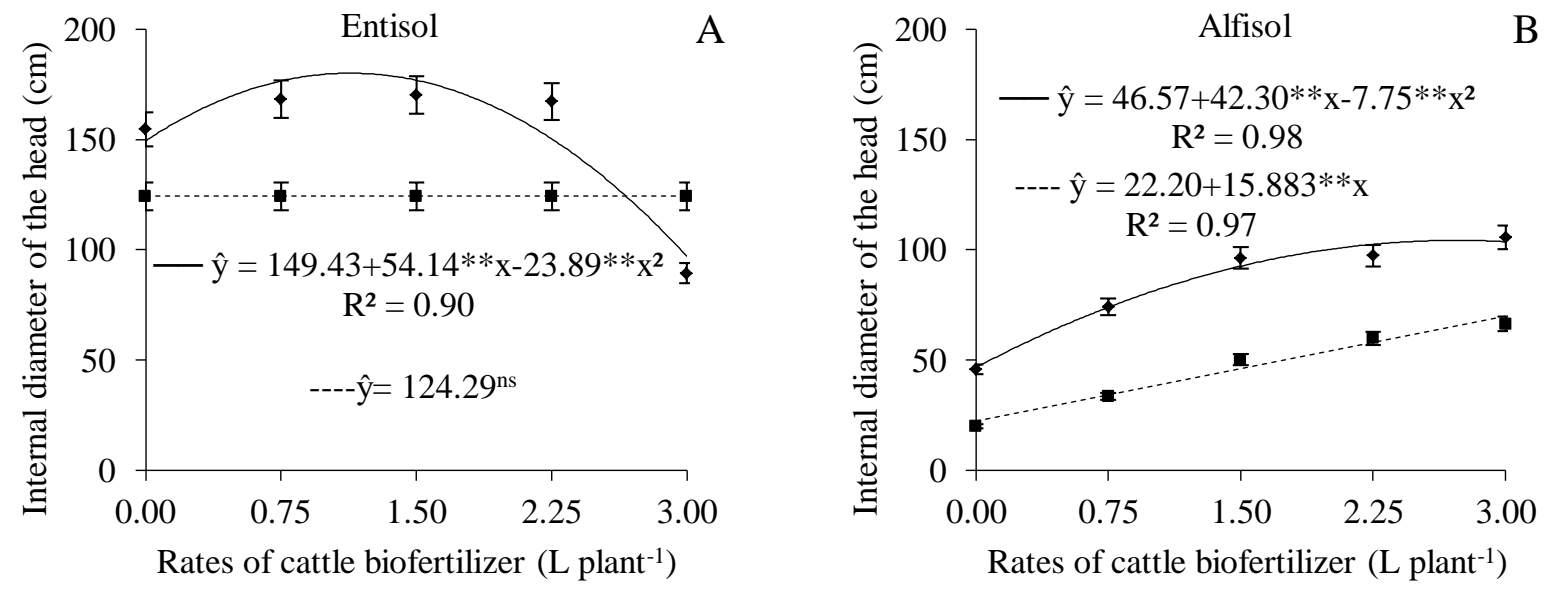

Fig 1. Internal diameter of the head of sunflower Helium 253 cultivated in Entisol (A) and Alfisol (B), according to rates of cattle biofertilizer, with $100 \%(-)$ and $50 \%$ (---) of moisture retention capacity (MRC).

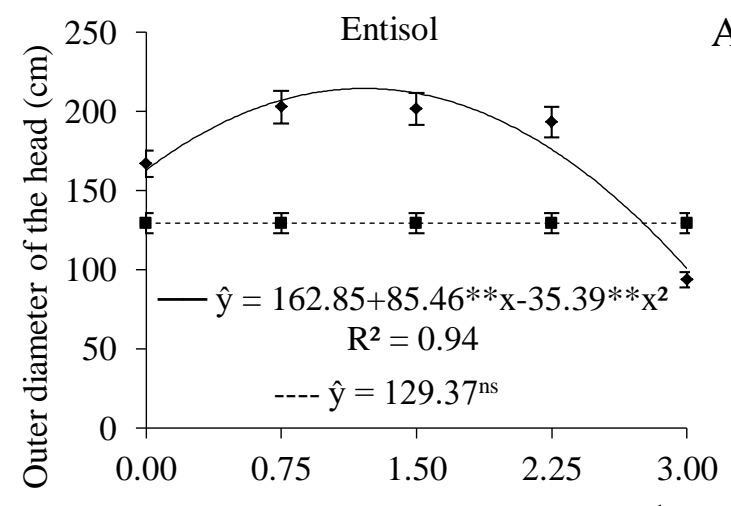

Rates of cattle biofertilizer $\left(\mathrm{L} \mathrm{plant}^{-1}\right)$
A

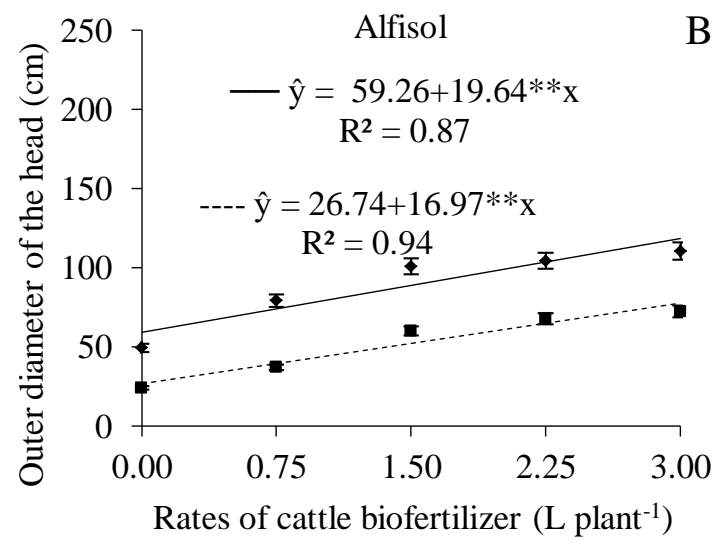

Fig 2. Outer diameter of the head of sunflower Helium 253 cultivated in Entisol (A) and Alfisol (B), according to rates of cattle biofertilizer, with $100 \%(-)$ and $50 \%$ (---) of moisture retention capacity (MRC). 

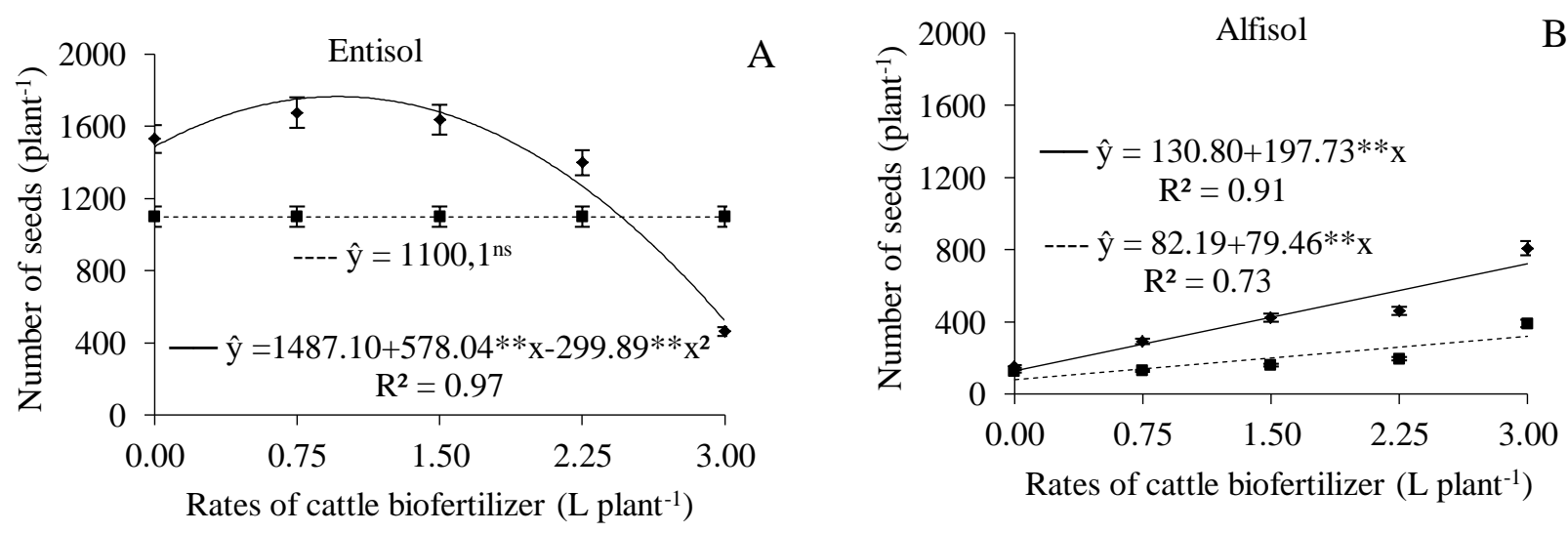

Fig 3. Number of seeds per plant of sunflower Helium 253 cultivated in Entisol (A) and Alfisol (B), according to the rates of cattle biofertilizer, with $100 \%(-)$ and $50 \%$ (--) of moisture retention capacity (MRC).
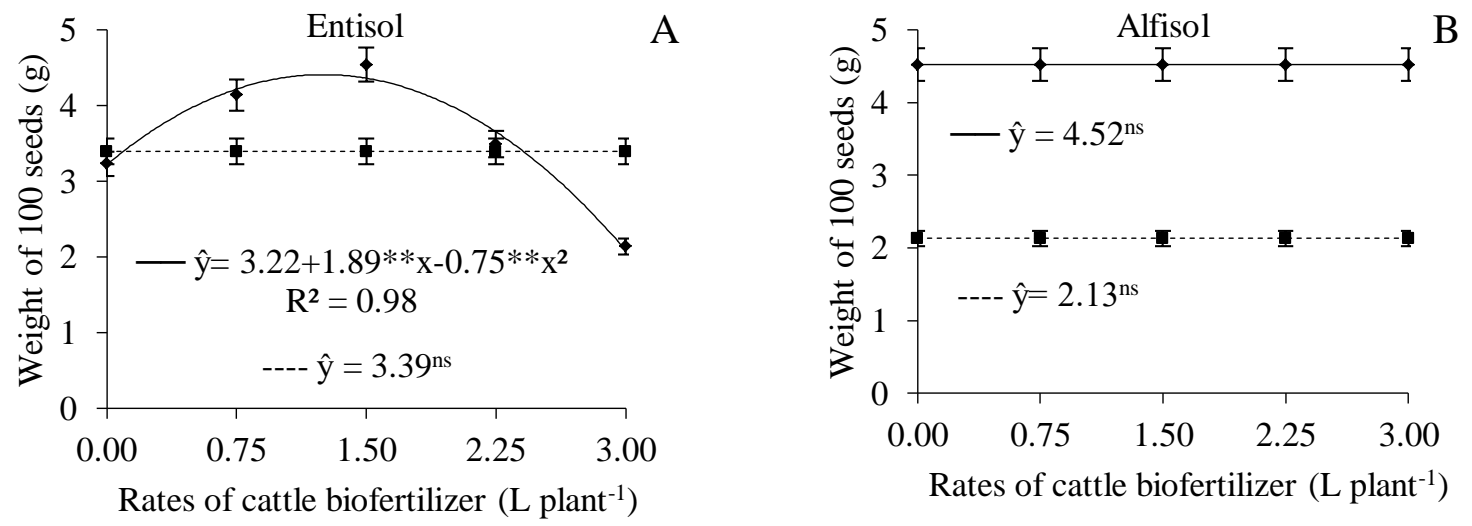

Fig 4. Weight of 100 seeds of sunflower Helium 253 cultivated in Entisol (A) and Alfisol (B), according to rates of cattle biofertilizer, with $100 \%(-)$ and $50 \%$ (---) of moisture retention capacity (MRC).
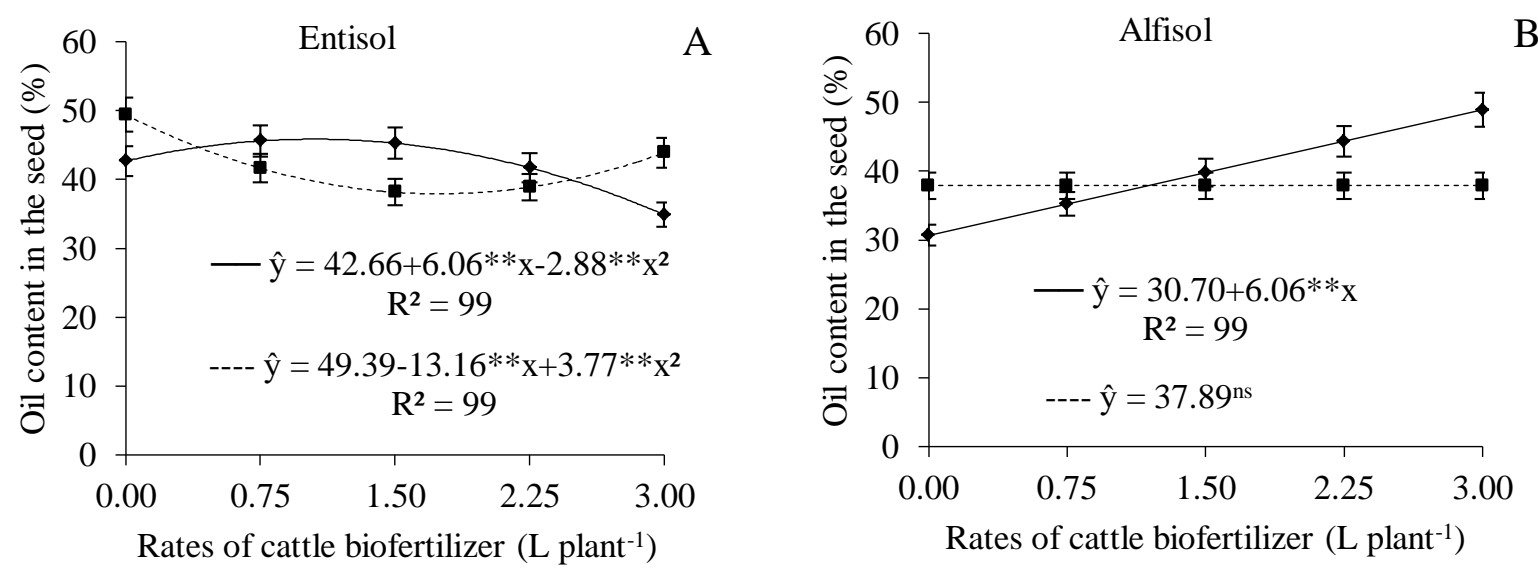

Fig 5. Oil content in the seeds of sunflower Helium 253 cultivated in Entisol and Alvisol (B), according to rates of cattle biofertilizer, with $100 \%(-)$ and $50 \%$ (---) of moisture retention capacity (MRC). 

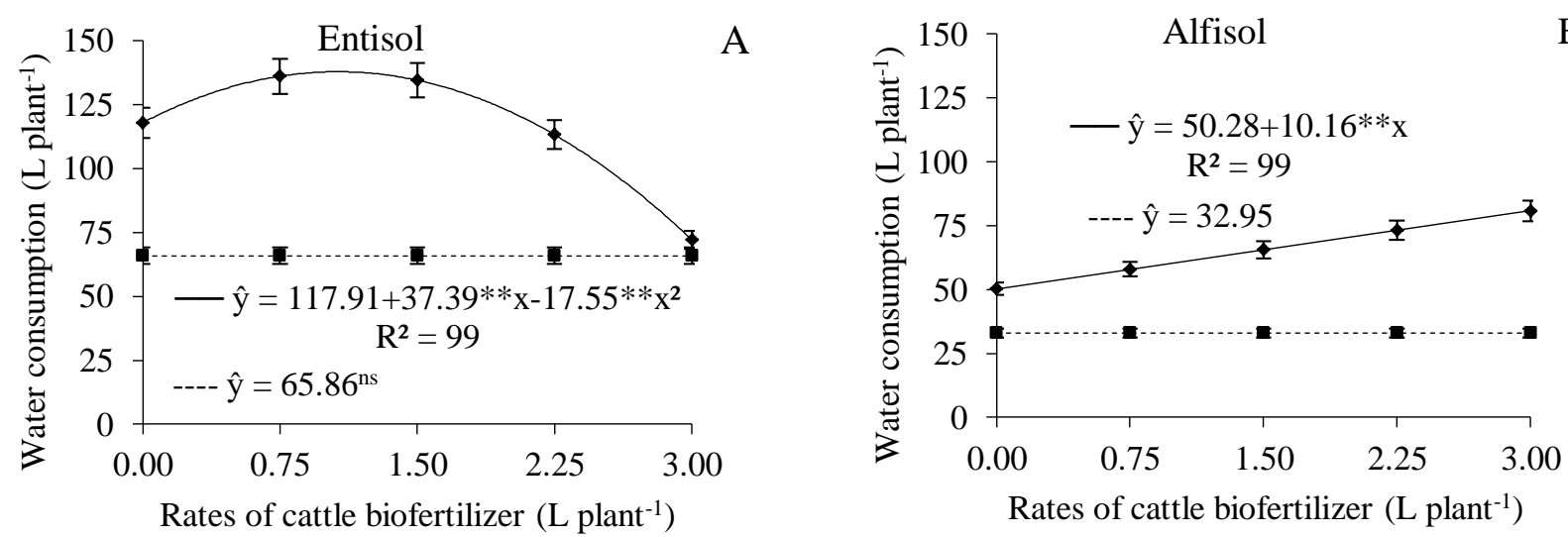

Fig 6. Water consumption per plant of sunflower Helium 253 cultivated in Entisol (A) and Alfisol (B), according to rates of cattle biofertilizer, with $100 \%(-)$ and $50 \%$ (---) of moisture retention capacity (MRC).

\section{Results}

According to the summary of the variance analysis (Table 2), it was verified that, except for the outer diameter of the head and the weight of 100 seeds per plant, there was a significant effect by the $F$ test $(p<0.01)$ of the triple interaction composed by the factors: available water levels, soil types and rates of cattle biofertilizer. It can be observed in the Fig. $1 \mathrm{~A}$ that there was a significant quadratic response $(p<0.01)$ for the internal diameter of the head as a function of the rates of cattle biofertilizer applied in Entisol, the highest value being $180.11 \mathrm{~cm}$, obtained with the estimated rate of $1.13 \mathrm{~L} \mathrm{plant}^{-1}$, decreasing with the increase of the rate, in conditions of $100 \%$ MCR. When under conditions of $50 \%$ MCR in Entisol, there was no significant effect of the rates of cattle biofertilizer on the internal diameter of the head, with an average value of $124.29 \mathrm{~cm}$. The plants submitted to the highest volume of water available in the soil $(100 \%$ MCR) presented superiority of $44.91 \%$ in relation to those cultivated with $50 \%$ MCR. The regression analysis for the rates of cattle biofertilizer applied in Alfisol, referring to the internal diameter of the head, can be visualized in Fig. $1 B$, where a quadratic effect is verified in the plants cultivated with $100 \%$ MCR, with a maximum value of 104.27 $\mathrm{cm}$ for the estimated rate of $2.72 \mathrm{~L}_{\text {plant }}{ }^{-1}$. For the regression regarding the internal diameter of the head in Alfisol with $50 \% \mathrm{MCR}$, there is an increase of $4.76 \mathrm{~cm}$ for each unitary increase of the rate cattle biofertilizer, reaching a maximum value of $69.86 \mathrm{~cm}$ with the rate of $3 \mathrm{~L} \mathrm{plant}^{-1}$. It is observed superiority of $49.25 \%$ of the plants submitted to $100 \%$ MCR in comparison to the same treatments with $50 \%$ MCR. When comparing the two soils, a superiority of 72.73 and $77.91 \%$ of the internal diameter of the head was observed in the plants in Entisol, in comparison to the plants cultivated in Alfisol with 100 and $50 \%$ MCR, respectively. The sunflower hybrid Helium 253 responded similarly as for the increase in internal and outer diameter of the head in function of the rates of cattle biofertilizer applied in Entisol, maintained at $100 \% \mathrm{MCR}$. It was verified, through regression analysis, that the mathematical model that best fit the data for the outer diameter of the head was quadratic, with significant effect $(p<0.01)$, obtaining the maximum value of $214.29 \mathrm{~cm}$ at the estimated rate of $1.20 \mathrm{~L} \mathrm{plant}^{-1}$, decreasing with application of rates above the estimated (Fig. 2A). The outer diameter of plants cultivated in Entisol submitted to $50 \%$ MCR did not present a significant response for the unfolding of the interaction cattle biofertilizer $x$ moisture retention capacity $x$ soils, presenting a mean value of 129.37 $\mathrm{cm}$. The plants cultivated without water deficit (100\% MCR) were superior in $86.51 \%$ to the same treatments submitted to $50 \%$ MCR. In Fig. 2B, the regressions for the factor dose of cattle biofertilizer applied in Alfisol can be visualized, showing a linear increase in the outer diameter of the head as the rates of cattle biofertilizer in the soil were increased, varying from 5.89 to $5.09 \mathrm{~cm}$ per unitary increase of the rates, reaching the maximum values of 118.2 and $77.67 \mathrm{~cm}$, when the plants were submitted to 100 and $50 \%$ MCR in the soil, respectively. Statistically, it was found that the quadratic equation was also the one that best fit the number of seeds per plant data, in the plots cultivated in Entisol kept at $100 \%$ MCR of soil (Fig. 3A), obtaining the maximum number of seeds equal to 1765.0 , achieved with the cattle biofertilizer rate estimated at $0.96 \mathrm{~L}_{\text {plant }}{ }^{-1}$. When in conditions of $50 \% \mathrm{MCR}$, no significant effect of the interaction was observed, with an average of 1100 seeds (plant $^{-1}$ ). In Fig. 3B, the regression for the factor rate of cattle biofertilizer can be visualized, with an increasing linear tendency of the number of seeds per plant as the rates of cattle biofertilizer increased in the soil maintained at $100 \%$ MCR, with an increase of $57.88 \%$ of seeds for each unitary increase of the percentage of rate cattle biofertilizer in Alfisol, reaching a maximum value of 709.6 seeds with the highest input rate. Concerning the regression analysis of the number of seeds (plant ${ }^{-1}$ ) in relation to $50 \%$ MCR in the soil, there was an increasing linear trend, with the maximum number of seeds of 319.71 , obtained with the highest rate of the applied input. Statistically, it was found that the quadratic equation was the one that best fit the data weight of a hundred seeds in the plants that were submitted to $100 \%$ MCR in Entisol, with the highest value resulting in 4.54 g (Fig. 4A). In the unfolding of the interaction between soil types, available water levels and rates of cattle biofertilizer, there was no significant effect of the weight of a hundred seeds in the plants cultivated in Entisol submitted to $50 \%$ MCR, with a mean of $3.39 \mathrm{~g}$; as for Alfisol, there was no significant effect regardless of the level of available water in the soil, presenting an average of 4.52 and $2.13 \mathrm{~g}$ in the plants cultivated with 100 and $50 \%$ of MCR, respectively (Fig. 
$4 \mathrm{~A}$ and $\mathrm{B})$. The regression analyses for the variable oil content in the seeds in relation to the levels of cattle biofertilizer applied in Entisol, independently of the level of available water in the soil, showed that the best adjustments were represented by a quadratic curve (Fig. 5A). It was observed that the increase in the rate resulted in an increase in the oil content of the seeds, where the maximum increase (41.30\%) was estimated at $1.05 \mathrm{~L} \mathrm{plant}^{-1}$ of the cattle biofertilizer under the conditions of $100 \%$ MCR. From the maximum point there is a tendency to reduce the oil content of the seeds. When the plants were submitted to $50 \% \mathrm{MCR}$, there was a decrease in function of the estimated rate of $1.74 \mathrm{~L} \mathrm{plant}^{-1}$, and from this on, an increase, reaching the value of oil in the seeds equal to $43.43 \%$, referring to the rate of cattle biofertilizer of $3.0 \mathrm{~L} \mathrm{plant}^{-1}$. For the oil content of sunflower seeds in function of the levels of cattle biofertilizer applied in Alfisol, when the plants were cultivated with $100 \% \mathrm{MCR}$, it is possible to observe an increasing linear tendency of the percentage of oil in the seeds. However, for treatments with $50 \%$ MCR, no statistical difference was observed, with a mean oil content in the seeds of $37.89 \%$ (Fig. 5B). From the regression analysis, it was verified that in Entisol the water consumption by plants reached the maximum value of $137.79 \mathrm{~L}$, when under conditions of $100 \% \mathrm{MCR}$, at the cattle biofertilizer rate estimated at $1.06 \mathrm{~L} \mathrm{plant}^{-1}$, and decrease with the increased rates. For the plants submitted to water deficit (50\% MCR), water consumption data did not fit any mathematical model, with a mean of $65.86 \mathrm{~L} \mathrm{plant}^{-1}$ (Fig. 6A). For the water consumption of the plants cultivated in Alfisol, there was an increase of $3.77 \%$ for each unitary increase of the cattle biofertilizer, in plants cultivated with $100 \%$ MCR (Fig. 6B), that is, for each $1 \%$ of biofertilizer added to the soil, it is estimated by the regression equation that the plant increased $3.05 \mathrm{~L}$ of water in its consumption during the cycle. While in water deficit conditions ( $50 \%$ MCR), the water consumption by the plants was adjusted to the quadratic model, reaching a maximum consumption of 34.66 $\mathrm{L}$ corresponding to the rate $3.0 \mathrm{~L} \mathrm{plant}^{-1}$.

\section{Discussion}

The fact that the highest values referring to the variables of production are observed when the plants are cultivated in Entisol in relation to Alfisol may have occurred due to the $68.42 \%$ superiority of potassium content present in Entisol. Potassium acts on the regulation of water demand parameters of plants, since it is the main solute involved in water absorption by the cell, maintenance of turgescence pressure and cell stretching, and also in the regulation of stomatal opening (González et al., 2015). Low potassium, as can be observed in Alfisol, increases the susceptibility of plants to water deficit, which may have contributed to the fact that the plants cultivated in this soil have anticipated the end of the phenological vegetative stage; without, however, having completed the full development of the photosynthetic apparatus, limiting the ability of the plant to intercept and use light. This situation converges to a condition in which less developed plants have smaller amount of accumulated photoassimilates and, therefore, less capacity to translocate them to the grains in the filling phase, reflecting in significant reductions in production (Mengel and Kirkby, 2001; Taiz and Zeiger, 2013). Other studies have also verified that the application of potassium sulphate significantly improves growth, seed yield, rate of photosynthesis, transpiration, stomatal conductance, water use efficiency, leaf turgor and larger aerial part of the sunflower (Mengel and Kirkby, 2001; Akram et al., 2009), which reinforces the idea exposed in this discussion. In addition to the higher potassium content, Entisol also showed higher amounts of calcium, magnesium, sodium, phosphorus and organic matter, which justifies the higher values of production of sunflower observed in this type of soil. Regardless of the type of soil studied, it is possible to observe, through the variables analyzed, that the plants cultivated with $100 \%$ MCR presented higher values of production, suggesting that the sunflower cultivar Helium 253 is sensitive to the water deficit it was submitted $(50 \%$ MCR). This occurs when the plant feels the need to close the stomata to avoid greater losses of cellular turgor through transpiration, which causes significant inhibition of photosynthesis, negatively affecting physiological and biochemical processes, such as respiration, translocation, carbohydrates and nutrient absorption metabolism, which reduce plant growth (Heidari and Karami, 2014). Other studies in the literature have also reported a decrease in the production of several sunflower cultivars when submitted to water deficit, and gains when water availability in the soil is high at values close to $100 \%$ AW (Silva et al., 2007; Maia Filho et al., 2013). The application of rates of cattle biofertilizer up to the estimated value of $1.05 \mathrm{~L} \mathrm{plant}^{-1}$ increased the production of the plants cultivated in Entisol, decreasing as the rates increased. Possibly, this tendency occurred due to a nutritional imbalance caused by the excess of nutrients supplied with the rates above the estimated, especially since the Entisol used in the experiment had better fertility conditions compared to Alfisol. This way, the linear trend of sunflower production is also justified in function of the rates of cattle biofertilizer in Alfisol, because in addition to the biofertilizer providing nutrients to the plants, it can improve the physical attributes of the soil, such as porosity and the relationship of micro and macropores (Castro et al., 2006) as well as influence the amount of bacteria and fungi that participate in the nutrient cycling process, and maintain the balance of microbial flora (Shen et al., 2013). Concerning the higher water consumption by the plant in Entisol, when under conditions of $100 \% \mathrm{MCR}$, this occurred due to water being the main constituent of vegetal tissues, and may correspond up to $95 \%$ of the total weight of the green mass, being responsible for the maintenance of leaf turgidity (Floss, 2006). Therefore, the larger the plant surface exposed to solar radiation, the greater its transpiration and consequently the water consumption for the maintenance of cellular turgidity and plant temperature (Taiz and Zeiger, 2013).

\section{Materials and Methods}

\section{Localization, experimental procedure, treatments and plant material}

The experiment was carried out from September 2012 to March 2013, in a greenhouse at the Center for Human and Agrarian Sciences, of the Paraíba State University, Campus IV, Catolé do Rocha municipality, Paraíba state, Brazil, located through the geographical coordinates: latitude 
$6^{\circ} 20^{\prime} 38^{\prime \prime}$ South, longitude $37^{\circ} 44^{\prime} 48^{\prime \prime}$ West at an altitude of $275 \mathrm{~m}$.

The soils used in the experiment were classified as Neossolo Flúvico and Luvissolo Háplico (Santos et al., 2006), and as Entisol and Luvisol (USDA, 2014), from the municipalities of Catolé do Rocha and Brejo dos Santos in the state of Paraíba, Brazil.

The samples of these soils were collected in a layer 0-0.20 $\mathrm{m}$ deep, air dried, screen sieved with a $2.0 \mathrm{~mm}$ mesh opening, and later characterized as to the chemical and physical attributes according to the methods adopted by Embrapa (1997), with the following results: Entisol: sand = $820 \mathrm{~g} \mathrm{~kg}^{-1}$; silt $=125 \mathrm{~g} \mathrm{~kg}^{-1}$; clay $=55 \mathrm{~g} \mathrm{~kg}^{-1}$; field capacity $=$ $22.82 \%$ of the volume; permanent wilting point $=6.54 \%$ by volume; available water $=16.28 \%$ by volume; $\mathrm{pH}\left(\mathrm{H}_{2} \mathrm{O}\right)=$ 7.44; $\mathrm{Ca}^{2+}=4.44 \mathrm{cmol}_{\mathrm{c}} \mathrm{kg}^{-1} ; \mathrm{Mg}^{2+}=2.81 \mathrm{cmol}_{\mathrm{c}} \mathrm{kg}^{-1} ; \mathrm{Na}^{+}=$ $0.26 \mathrm{cmol}_{\mathrm{c}} \mathrm{kg}^{-1} ; \mathrm{K}^{+}=0.57 \mathrm{cmol}_{\mathrm{c}} \mathrm{kg}^{-1} ; \mathrm{H}^{+}=0,0 \mathrm{cmol}_{\mathrm{c}} \mathrm{kg}^{-1} ; \mathrm{Al}^{3+}=$ $0 \mathrm{cmol}_{\mathrm{c}} \mathrm{kg}^{-1} ; \mathrm{O} . \mathrm{M}=6.9 \mathrm{~g} \mathrm{~kg}^{-1} ; \mathrm{P}=53.3 \mathrm{mg} \mathrm{kg}^{-1}$; Alfisol: sand $=$ $655 \mathrm{~g} \mathrm{~kg}^{-1}$; silte $=228 \mathrm{~g} \mathrm{~kg}^{-1}$; clay $=117 \mathrm{~g} \mathrm{~kg}^{-1}$; field capacity $=$ $19.60 \%$ of the volume; permanent wilting point $=5.70 \%$ by volume; available water $=13.06 \%$ by volume $\mathrm{g} \mathrm{kg}^{-1} ; \mathrm{pH}\left(\mathrm{H}_{2} \mathrm{O}\right)$ $=7.81 ; \mathrm{Ca}^{2+}=3.97 \mathrm{cmol}_{\mathrm{c}} \mathrm{kg}^{-1} ; \mathrm{Mg}^{2+}=2.45 \mathrm{cmol}_{\mathrm{c}} \mathrm{kg}^{-1} ; \mathrm{Na}^{+}=$ $0.15 \mathrm{cmol}_{\mathrm{c}} \mathrm{kg}^{-1} ; \mathrm{K}^{+}=0.18 \mathrm{cmol}_{\mathrm{c}} \mathrm{kg}^{-1} ; \mathrm{H}^{+}=0.06 \mathrm{cmol}_{\mathrm{c}} \mathrm{kg}^{-1} ; \mathrm{Al}^{3+}$ $=0 \mathrm{cmol}_{\mathrm{c}} \mathrm{kg}^{-1} ; \mathrm{O} . \mathrm{M}=4.5 \mathrm{~g} \mathrm{~kg}^{-1} ; \mathrm{P}=14.3 \mathrm{mg} \mathrm{kg}^{-1}$. For this experiment, the hybrid Helium 253 sunflower was chosen, although it is still little studied, the results obtained so far makes us believe that it is a plant with potential to be cultivated in semiarid regions.

\section{Treatments}

The treatments were arranged in a completely randomized design with $2 \times 2 \times 5$ factorial, referring to two levels of available water ( 100 and $50 \%$ of moisture retention capacity (MRC)), two soils (Entisol and Alfisol) and five rates of cattle biofertilizer $\left(0,0.75,1.5,2.25\right.$ and $\left.3.00 \mathrm{~L} \mathrm{plant}^{-1}\right)$, totaling 20 treatments with nine replications and 180 experimental plots. Each experimental unit consisted of a plastic pot with capacity for 30 liters and a sunflower (Helianthus annuus L.) plant from the hybrid Helium 253.

\section{Establishment and management of the experiment}

The sowing was performed at a depth of $5 \mathrm{~cm}$, using seven seeds per pot, distributed equidistantly. The seedling emergence began on the fourth day after sowing (DAS), at the ninth DAS the first thinning was made, leaving three plants per pot and the second pruning at 15 DAS, leaving only one plant, the most vigorous one. The biofertilizer rates were applied three times in 20 days, starting after the second pruning.

Soil water content was monitored daily by TDR probe model PR2/6 (Time Domain Reflectometry) in the treatments of 100 and $50 \%$ of moisture retention capacity (MRC) in four depth intervals: $0-10 ; 10-20 ; 20-30$ and 30-40 $\mathrm{cm}$; from the readings made with the probe model PR 2 for each depth, the values were put in a spreadsheet that accounted for the water content of each layer (four layers of $10 \mathrm{~cm}$ each), making a balance of water content along the existing soil profile as determined in accordance with the following equation proposed by Barbosa et al. (2016): $\mathrm{MCR}=(\mathrm{CC}-\mathrm{CA}) / 100) \times \mathrm{V}$
Where: $\mathrm{MCR}=$ Moisture retention capacity in $\mathrm{cm} ; \mathrm{CC}=$ Moisture at field capacity (dry weight basis); $C A=$ Current capacity of soil and V = Soil volume.

Based on the probe readings a water balance was performed, which recorded the consumption of water by such treatments. Irrigation of the pots was done daily by hand with the aid of a graduated cylinder. At 90 DAS the irrigation was suspended, based on the criterion of the physiological maturity of the grains (Silva et al., 2007); on this same period, all the plants were in the phenological stage R9 (head inclined down, with back and bracts with a color between yellow and brown).

\section{Preparation of cattle biofertilizer}

The cattle biofertilizer was obtained through anaerobic fermentation, where $70 \mathrm{~kg}$ of fresh cattle manure was mixed, from animals raised in the semi-intensive system, with $100 \mathrm{~L}$ of slightly saline water $-\mathrm{CE}=0.8 \mathrm{dS} \mathrm{m} \mathrm{m}^{-1}, 5 \mathrm{~kg}$ of crystal sugar and $5 \mathrm{~L}$ of milk were added to accelerate the metabolism of bacteria, and adding $2 \mathrm{~kg}$ of leaves and branches of the leguminous plant beans-macassar (Vigna unguiculata (L.) Walp), in the plastic biodigester with capacity for 200 liters, kept tightly closed for 45 days. During the fermentation the methane gas produced was released through a duct connected to the upper base and its end submerged in water (Santos, 1992). As a result of being applied in liquid form, composition analysis was performed following common procedures for water sample for irrigation, according to the data in table 1 , congenerous suggestion of Cavalcante et al. (2010).

\section{Traits measured}

To evaluate the sunflower production, the following variables were measured: internal diameter (IDH) and outer diameter of the head $(\mathrm{ODH})$, number of seeds per plant (NSP), weight of 100 seeds (W100S) and oil content in seeds (OCS). The oil extraction from the sunflower seeds was carried out by the Soxhlet method, using the petroleum ether as a solvent and then calculating the results as a percentage (dry basis) according to Thomaz et al. (2012). It was also evaluated the water consumption per plant (WCP), obtained by quantifying the water volume applied in each treatment, during the period comprising the phenological stage VE (cotyledons emergence) until the physiological maturation phase R9.

\section{Statistical analysis}

Data were submitted to variance analysis, $\mathrm{F}$ test, regression for the quantitative factors and Tukey test for the qualitative data using the statistical program Sisvar ${ }^{\circledR} 5.3$ (Ferreira, 2011).

\section{Conclusion}

Among the studied soils, under semiarid conditions, Entisol is the one that presents the best conditions for the production of sunflower Helium 253, being also the soil where the highest water consumption by plant occurs. For Entisol, it can be recommended the rate of cattle biofertilizer estimated in $1.05 \mathrm{~L} \mathrm{plant}^{-1}$, and for Alfisol, the 
rate of $3 \mathrm{~L} \mathrm{plant}^{-1}$ can be recommended. Regardless of the soil used, the highest production values are obtained when the soil is irrigated with $100 \%$ MCR.

\section{Acknowledgements}

The authors thank the State University of Paraíba (UEPB) for providing the necessary infrastructure to carry out this research, and the National Council for Scientific and Technological Development (CNPq), for granting a Scientific Initiation scholarship to the first author.

\section{References}

Akram MS, Ashraf M, Akram NA (2009) Effectiveness of potassium sulfate in mitigating salt-induced adverse effects on different physio-biochemical attributes in sunflower (Helianthus annuus L.). Flora. 204:471-483.

Barbosa MA, Dantas GF, Mesquita EF, Nascimento FR, Silva AF, Sá FVS, Ferraz RLS (2016) Sunflower behavior of on soils with water availability and addition of cattle biofertilizer. Afr. J. Agr. Res. 41:3913-3920.

Castro C, Moreiras A, Oliveira RF, Dechen AR (2006) Boro e estresse hídrico na produção do girassol. Ver. Ciên. Agrot. 30:214-220.

Cavalcante LF, Vieira MS, Santos AF, Oliveira WM, Nascimento JAM (2010) Água salina e esterco bovino líquido na formação de mudas de goiabeira cultivar Paluma. Ver. Bras. Frutic. 32:251-261.

EMBRAPA (1997) Empresa Brasileira de Pesquisa Agropecuária. Centro Nacional de Pesquisa de Solos. Ministério da Agricultura e do Abastecimento. Manual de métodos de análise de solo. 2th ed, Rio de Janeiro, EMBRAPA.

Ferreira DF (2011) Sisvar: a computer statistical analysis system. Ciên. e Agrote. 35:1039-1042.

Floss EL (2006) Fisiologia das Plantas Cultivadas: O Estudo que Está por Trás do que Se Vê. 3th ed. Passo Fundo, UPF.

Gatto AD, Mengarelli C, Pedretti EF, Duca D, Pieri S, Mangoni L, Signor M, Raccuia SA, Melilli MG (2015) Adaptability of sunflower (Helianthus annuus L.) high oleic hybrids to different Italian areas for biodiesel production. Ind. Crop. Prod. 75:108-117.
González MB, Quintero JM, Mateo MJG, Fournier JM, Benlloch M (2015) Effect of water stress and subsequent re-watering on $\mathrm{K}^{+}$and water flows in sunflower roots. $\mathrm{A}$ possible mechanism to tolerate water stress. Environ. Exp. Botany. 118:78-84.

Heidari M, Karami V (2014) Effects of different mycorrhiza species on grain yield, nutrient uptake and oil content of sunflower under water stress. J. Saudi. Soc. Agri. Sci. 13:913.

Maia Filho, FCF, Mesquita EF, Guerra HOC, Moura MFM, Chaves LHG (2013) Effect of cattle manure on sunflower production and water use in two types of soil. Ceres. 60, 397-405.

Mengel K, Kirkby EA, (2001) Principles of Plant Nutrition. Dordrecht, Kluwer Academic Publishers.

Oliveira A (2015) Propriedades do óleo de girassol. Centro de Produções Técnicas (CPT). Accessed 29 August 2015. Available: http://www.cpt.com.br/cursos-agroindustriabiocombustivel/artigos/propriedades-do-oleo-de-girassol.

Rivera-Cruz MC, Trujillo NA, Córdova GB, Kohler J, Fuensanta C, Roldán A (2008) Poultry manure and banana waste are effective biofertilizer carriers for promoting plant growth and soil sustainability in banana crops. Soil. Bio. Bioch. 40:3092-3095.

Santos ACV (1992) Biofertilizantes líquido: o defensivo agrícola da natureza. 2th ed. Niterói, EMATER, RIO.

Santos HG, Jacomine PKT, Anjos LHC, Oliveira VA, Oliveira JB (2006) Sistema Brasileiro de Classificação dos Solos. 2th ed. Rio de Janeiro, Embrapa Solos.

Shen Z, Zhong S, Wang Y, Wang B, Mei X, Li R, Ruan Y, Shen Q (2013) Induced soil microbial suppression of banana fusarium wilt disease using compost and biofertilizers to improve yield and quality. Euro. J. Soil. Bio. 57:1-8.

Silva MLO, Faria MA, Morais AR, Andrade GP, Lima EMC (2007) Crescimento e produtividade do girassol cultivado na entressafra com diferentes lâminas de água. Rev. Bras. Eng. Agr. Amb. 11:482-488.

Taiz L, Zeiger E (2013) Fisiologia Vegetal. Porto Alegre, Artmed, 5 th ed.

Thomaz GL, Zagonel J, Colasante LO, Nogueira RR (2012) Produção do girassol e teor de óleo nas sementes em diferentes épocas de semeadura no Centro-Sul do Paraná. Ciên. Rural. 42:203-208.

USDA-United States Department of Agriculture (2014) Keys to Soil Taxonomy. 12th ed. Washington. 